\title{
DETERMINANT CAPITAL BUFFER \\ STUDI KASUS PADA BANK UMUM SWASTA NASIONAL NON DEVISA DI INDONESIA PERIODE TAHUN 2012-2016
}

\author{
Oleh: \\ KADEK NOVI ANJARWATI \\ IBNU HAJAR \\ RISKI AMALIA MADI \\ (Jurusan Manajemen Fakultas Ekonomi dan Bisnis Universitas Halu Oleo Kendari)
}

\begin{abstract}
ABSTRAK
Penelitian ini bertujuan untuk menguji secara empiris faktor-faktor yang mempengaruhi capital buffer pada bank. penelitian ini diuji dengan enam variabel independen yaitu non performing loan, gross domestic product, return on equity, loan growth, loan to total asset dan size. Objek pada penelitian ini adalah Bank Umum Swasta Nasional Non Devisa dengan menggunakan teknik purposive sampling penulis memilih sembilan bank sebagai sampel. Penelitian ini menggunkan analisis data panel diperoleh dari laporan triwulanan periode penelitian selama 5 tahun. Penelitian ini menggunakan data sekunder dengan bantuan aplikasi Eviews 9.

Hasil penelitian menemukan bahwa NPL dan loan growth memiliki pengaruh positif dan signifikan terhadap capital buffer sedangkan pengaruh negatif signifikan ditunjukan oleh variabel LOTA. Tiga variabel lainnya yaitu GDP, ROE dan Size memilki pengaruh positif tidak signifikan.
\end{abstract}

Kata kunci: capital buffer, non-performing loan, gross domestic product, return on equity, loan growth, loan to total asset dan size.

\section{PENDAHULUAN}

Modal bank memiliki peran yang sangat penting bagi bank -bank konvensional dalam menjalankan fungsi serta kelangsungannya (Fikri, 2012). Tidak hanya sebagai penunjang kegiatan operasional, modal bank juga menjadi media untuk meningkatkan reputasi bank.

Pada krisis keuangan global tahun 2007-2008 sebagian besar lembaga keuangan diseluruh dunia ambruk dan diselamatkan oleh pemerintah (Erkens,2012). Pemerintah sebagai pemegang kekuasaan tertinggi pada suatu negara memiliki peran penting dalam kebijakan perbankan. Prilaku berisiko bank menyebabkan banyak negara melakukan pembaruan standar bank untuk membantu regulator dan pemegang saham dalam memperhatikan modal bank (Lijeblom, 2017).

Syaifuddin,D.T (2009) berpendapat bahwa pihak otoritas moneter dan manajemen bank harus dapat membuat kebijakan yang dapat mengeliminir risiko yang ditimbulkannya, misalnya melalui kebijakan penjaminan simpanan dana masyarakat yang dihimpun, sehingga masyarakat yang menyimpan dananya, baik dalam bentuk giro, tabungan, deposito berjangka, sertifikat deposito berjangka, maupun dalam bentuk simpanan lainnya di bank, akan merasa aman bahwa dananya dapat ditarik setiap saat sesuai dengan perjanjian yang telah ditetapkan antara nasabah dengan banknya.

Capital Adeqaucy Ratio (CAR) merupakan ukuran yang digunakan untuk mengukurkesehatan bank. CAR menunjukkan rasio antara seluruh aktiva bank yangmengandung risiko (kredit, penyertaan, surat berharga, tagihan pada bank lain) ikutdibiayai dari modal sendiri bank, di samping memperoleh dana dari sumber-sumberdi luar bank, seperti dana masyarakat, pinjaman (Haryanto, 2015).

Berdasarkan Peraturan Bank Indonesia Nomor 15/ 12 /PBI/2013 Tentang Kewajiban Penyediaan Modal Minimum Bank Umum pada Pasal 2 ayat 1 menyebutkan bahwa "Bank wajib menyediakan modal minimum sesuai dengan profil risiko."

Pentingnya permodalan bagi bank, menyebabkan bank tidak hanyaberusaha untuk memenuhi ketentuan minimal CAR tetapi bank berusaha memperbesar CAR di atas minimum. 
Hingga 2016, rata-rata CAR bank di Indonesia adalah $21.43 \%$. Berada jauh dari ketentuan permodalan oleh Bank Indonesia yaitu 8\%. CAR bank yang diatas minimum berfungsi apabila bank ingin memitigasi risiko dari siklus bisnis (Durape, 2014). Selisih antara ketentuan CAR atau rasio kecukupan modal minimum dengan CAR yang dimiliki bank (diatas ketentuan dari ATMR menurut ketentuan Bank Indonesia) dikenal dengan Capital buffer. Capital buffer dalam industriperbankan berfungsi untuk mengantisipasi apabila terjadi peningkatan kerugian dimasa depan dan untuk mengantisipasi apabila modal menjadi langka dan mahalpada periode penurunan. (Haryanto;2015).

Komite Basel menganggap penentuan ukuran Capital buffer tersebut adalah tepat sebagai tugas pentingmanajemen risiko untuk bank. Manajemen risiko kredit yang sehat menurut IMF (2010) adalah yang tidak menyebabkan efek prosiklikal (procyclical effect). Dikatakan bersifat prosiklikal apabila provisi bank cenderung bergerak mengikuti siklus perekonomian dimana modal dan provisi cenderung relatif rendah pada saat ekonomi stabil dan cenderung tinggi pada saat kondisi ekonomi yang buruk (Bouvatier et. al, 2012; Bikker et. al, 2005)

Beberapa penelitian seperti yang dilakukan Atici (2013); Bayuseno (2014); Haryanto (2015); dan Fauzia (2016) menggunakan 6 variabel detrminasi untuk capital buffer dintaranya nonperforming loan, gross domestic product, return on equity, loan growth, loan to assets ratio, dan size.

Pentingnya penyediaan capital buffer dan adanya gap penelitian terdahulu tentang faktorfaktor penentu capital buffer, menjadi alasan untuk melakukan penelitian untuk melihat faktor determinan yang mempengaruhi Capital buffer (modal penyangga) pada bank umum swasta nasional non devisa di Indonesia.

\section{TINJAUAN PUSTAKA}

\section{MODAL BANK}

Rose (2002) menyatakan bahwa terdapat lima fungsi dari modal bank, pertama, modal melindungi dari risiko kegagalan dengan menyerap kerugian finansial dan operasional sampai manajemen dapat mengatasi masalah bank dan mengembalikan profitabilitasnya. Kedua, modal menyediakan dana yang dibutuhkan untuk beroperasi, Ketiga, modal meningkatkan kepercayaan masyarakat. Keempat, modal mendanai pertumbuhan perusahaan serta perkembangan pelayanan yang baru, program, dan fasilitas. Kelima, modal mengikuti regulator pertumbuhan bank, dan membantu pertumbuhan setiap bank untuk dapat menjalankan aktivitasnya secara berkelanjutan dalam waktu yang lama.

Bank sentral dan pasar keuangan mengharuskan adanya peningkatan modal yang sejalan dengan pertumbuhan kredit serta risiko aset-aset bank lainnya. Dengan demikian, modal menjadi suatu perlindungan yang dapat menyerap kerugian di masa yang akan datang, yang sejalan dengan pertumbuhan risiko dari institusi perbankan. Sebuah bank dengan pertumbuhan kredit yang sangat cepat akan mendapat perhatian dari regulator dan pasar untuk memperlambat angka pertumbuhan kredit atau mengharuskan adanya penambahan modal.

Jadi, peraturan perbankan dibuat untuk membatasi risiko yang diterima perbankan. Dalam hal ini modal tidak hanya berperan meningkatkan kepercayaan masyarakat terhadap perbankan dan sistem perbankan, melainkan membantu melindungi Lembaga Penjamin Simpanan (LPS) dari kerugian (Fikri, 2012).

Regulasi perbankan yang diterapkan oleh bank sentral menjadi suatu instrumen penting dari perbankan moderen yang bertujuan mengatur capital buffer di saat kondisi ekonomi yang tidak menguntungkan, serta mekanisme dalam mengantisipasi risiko yang berlebihan (Rochet, 1992). Peraturan ini menjadi suatu instrumen yang penting dalam membangun kepercayaan masyarakat terhadap bank dan sistem keuangan, serta membatasi risiko yang mungkin diterima oleh perbankan. Dalam hal ini, modal berperan penting sebagai pelindung Lembaga Penjamin Simpanan (LPS) dari kerugian.

Peraturan permodalan bank atau yang biasa disebut persyaratan modal, mengatur besarnya modal yang harus dimiliki oleh bank terkait dengan aset-aset mereka. Basel committee on Banking Supervision banyak mempengaruhi persyaratan modal perbankan negara-negara di dunia. Pada 1988, Komite Basel memperkenalkan sistem pengukuran kecukupan modal yang disebut Basel Capital Accord. Sistem pengukuran kecukupan modal terbaru saat ini adalah Basel III. Basel III lebih sensitif terhadap risiko, namun lebih kompleks. Peraturan modal yang diromendasikan oleh Basel Accord, kemudian diimplementasikan oleh perbankan di seluruh dunia bertujuan untuk memastikan kesehatan dan stabilitas perbankan (Fikri, 2012).

Bank Indonesia menjelaskan bahwa Countercyclical Buffer adalah tambahan modal yang berfungsi sebagai penyangga (buffer) untuk mengantisipasi kerugian apabila terjadi pertumbuhan kredit dan/atau pembiayaan 
perbankan yang berlebihan sehingga berpotensi mengganggu stabilitas sistem keuangan. Capital buffer adalah selisih antara CAR yang ditetapkan oleh regulator dan CAR yang dimiliki oleh bank.

Tujuan kebijakan Countercyclical Capital buffer (CCB) adalah untuk mencegah timbulnya dan/atau meningkatnya risiko sistemik yang berasal dari pertumbuhan kredit yang berlebihan (excessive credit growth) (Bank Indonesia, 2016). Hal ini disebabkan karna adanya kecenderungan bank menyalurkan kredit lebih banyak pada periode ekonomi ekspansi (boom).

\section{PECKING ORDER THEORY}

Dalam keuangan perusahaan, pecking order theory menyatakan bahwa biaya pendanaan meningkat dengan informasi yang asimetris. Pendanaan berasal dari tiga sumber yaitu dana internal, utang, dan ekuitas baru. Bentuk sumber pendanaan yang diutamakan perusahaan adalah pendanaan dari internal, kemudian utang, dan ekuitas sebagai pilihan yang paling akhir. Oleh karena itu, proses sumber pendanaan perusahaan diawali dengan penggunaan pendanaan internal, ketika habis, maka perusahaan menerbitkan surat utang, dan ketika surat utang jumlahnya tidak lagi masuk akal untuk menerbitkan surat utang kembali, ekuitas diterbitkan.

Stewart C. Myers dan Nicolas Majluf menyatakan bahwa ekuitas memiliki biaya yang lebih mahal dibandingkan kewajiban bank lainnya dikarenakan informasi asimetris. Ekuitas juga dinilai tidak begitu menguntungkan, dikarenakan beban bunga utang dikenakan sebelum pajak. Kelebihan modal diharapkan memiliki hubungan yang negatif terhadap biaya ekuitas.

\section{TOO BIG TO FAIL THEORY}

Kane (2000); Mishkin (2006) menyatakan perilaku bank-bank besar yang cenderung memiliki capital buffer yang lebih rendah dibandingkan bank-bank kecil dikarenakan sifat terlalu besar untuk gagal (Too Big To Fail). Selain itu, bank besar mudah dalam mendapatkan pendanaan mereka dari pasar modal, dan memiliki kenggulan komparatif untuk mengatasi masalah informasi terkait pemantauan yang mendorong mereka mencapai keseimbangan antara cost supervision dan cost of equity.

\section{FAKTOR YANG MEMPENGARUHI CAPITAL BUFFER}

Menurut Atici (2013) ada beberapa faktor yang mempengaruhi disiplin yaitu:
1. Non-performing loan

Persentase perbandingan antara kredit bermasalah dan total kredit yang disalurkan bank.

2. Gross domestic product

Merupakan nilai barang dan jasa dalam suatu negara yang diproduksi oleh faktorfaktor produksi milik warga negara tersebut dan warga negara asing.

3. Return on equity

Adalah rasio yang sering dipergunakan oleh pemegang saham untuk menilai kinerja perusahaan yang bersangkutan. ROE mengukur besarnya tingkat pengembalian modal perusahaan

4. Loan growth

Yaitu persentase peningkatan jumlah penyaluran kredit bank yang diperoleh dengan mengurangi jumlah kredit pada tahun $t$ dikurangi jumlah kredit tahun $\mathrm{t}^{-}{ }_{1}$.

5. Loan to total assets

Yaitu rasio kredit yang diberikan kepada pihak ketiga dalam rupiah atau valuta asing, tidak termasuk kredit pada bank lain, terhadap dana pihak ketiga yang mencakup giro, tabungan dan deposito dalam rupiah atau valuta asing tidak termasuk dana dari bank lain.

6. Size

Adalah skala besarnya perusahaan yang dilihat dari total aktiva perusahaan pada akhir tahun. Total penjualan juga dapat digunakan untuk mengukur besarnya perusahaan.

\section{PENGARUH NPL TERHADAP CAPITAL BUFFER}

Apriani (2011) menyatakan bahwa kredit bermasalah (Non Performing Loan) adalah suatu keadaan dimana nasabah sudah tidak sanggup membayar sebagian atau seluruh kewajibannya kepada bank seperti yang telah diperjanjikan. Bank Indonesia mengelompokkan kredit bermasalah menjadi 3 yaitu kredit kolektibilitas Kurang Lancar, Diragukan dan Macet.

Non performing loan atau kredit macet sering digunakan sebagai indikator risiko bank. NPL yang tinggi menggambarkan risiko yang tinggi dan ketidakefisienan manajemen bank (Bayuseno, 2015). Bank dengan NPL yang tinggi dapat menggunakan capital buffer untuk meningkatkan reputasi.

$\mathrm{H}_{1}$ : Non Performing Loan berpengaruh positif pada capital buffer. 


\section{PENGARUH GDP TERHADAP CAPITAL BUFFER}

Pertumbuhan GDP memperlihatkan peningkatan income individu juga peningkatan pada perusahaan, oleh karena itu kemampuan untuk membayar hutang (kredit) menjadi meningkat. Pada saat kondisi ekonomi sedang baik, bank akan meningkatkan jumlah kredit dengan anggapan akan mendapat keuntungan yang lebih (Atici,2013). Sehingga pada saat kondisi ekonomi baik, jumlah capital buffer akan tergerus untuk disalurkan pada kredit.

$\mathrm{H}_{2}$ : Growt of GDP berpengaruh negatif pada capital buffer.

\section{PENGARUH ROE TERHADAP CAPITAL BUFFER}

Return on equity (ROE) adalah rasio yang sering dipergunakan oleh pemegang saham untuk menilai kinerja perusahaan yang bersangkutan. ROE mengukur besarnya tingkat pengembalian modal perusahaan (Sawir, 2005:20).

Tingginya laba dapat menjadi pengganti modal sebagai penyangga (buffer) menghadapi berbagai guncangan yang tidak terduga (Bayuseno, 2014). Dalam hal ini, bank akan mencari sumber dana yang murah untuk dijadikan modal penyangga. Sedangkan laba ditahan adalah sumber dana yang paling murah yang dapat diendapkan oleh bank.

$\mathrm{H}_{3}$ : Return on equity berpengaruh positif terhadap capital buffer.

\section{PENGARUH LOANS TERHADAP CAPITAL BUFFER}

Berdasarkan pada penelitian yang dilakukan oleh Atici (2013) menyatakan bahwa dengan mengendalikan LOANS maka dapat menginterpretasikan NPL. LOANS digunakan untuk menggambarkan pertumbuhan permintaan kredit. Jika pertumbuhan kredit meningkat bank seharusnya meningkatkan capital buffemya sebagai untuk mengendalikan risiko. Disisi lain jika jumlah permintaan kredit meningkat makan kebutuhan modal juga akan meningkat.

$\mathrm{H}_{4}$ : Loan Growth berpengaruh positif terhadap capital buffer.

\section{PENGARUH LOTA TERHADAP CAPITAL BUFFER}

Bank Indonesia mendefinisikan LOTA sebagai rasio kredit yang diberikan kepada pihak ketiga dalam rupiah atau valuta asing, tidak termasuk kredit pada bank lain, terhadap dana pihak ketiga yang mencakup giro, tabungan dan deposito dalam rupiah atau valuta asing tidak termasuk dana dari bank lain.

Rasio Hutang terhadap harta juga menjadi pertimbangan besarnya capital buffer bank. Hal ini terkait dengan risiko bank. Loansikanya adalah semakin tinggi rasio loan to total assets maka semakin berisiko suatu bank (Bayuseno, 2014). Maka diharapkan adanya hubungan positif antara LOTA dan capital buffer.

$\mathrm{H}_{5}$ : Loan to Total Assets berpengaruh positif terhadap capital buffer.

\section{PENGARUH SIZE TERHADAP CAPITAL BUFFER}

Penelitian yang dilakukan oleh Atici (2013) menunjukan hubungan negatif antara ukuran bank dan capital buffer. Maka dapat disimpulkan bahwa semakin besar ukuran suatu bank maka semakin rendah capital buffemya. Dikatakan pula pada penelitian oleh Mishkin (2006) pada Bayuseno (2014) bahwa bank besar cenderung menahan rasio modalnya dikarenakan sifat Too big to fail.

H6 : Size memiliki pengaruh negatif terhadap capital buffer.

$$
\text { Kanapkz Kouson }
$$

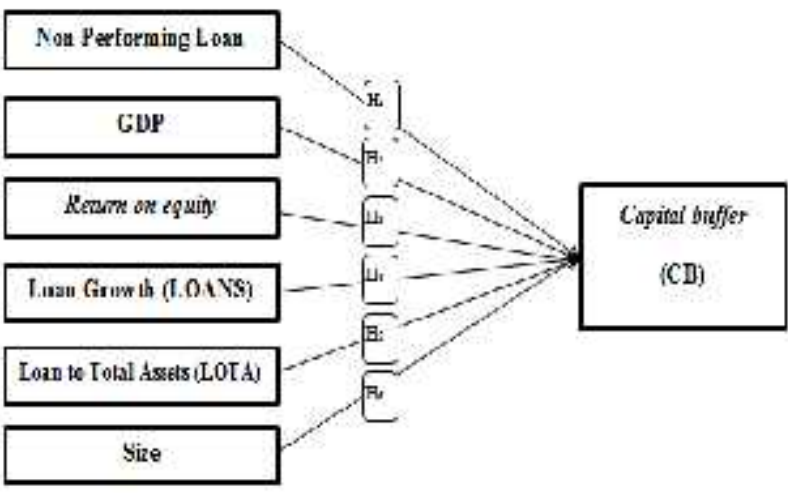

\section{METODE PENELITIAN \\ Populasi dan Sampel}

Populasi dalam penelitian ini adalah bank umum swasta nasional non devisa di Indonesia. Berdasarkan data Bank Indonesia, jumlah bank umum swasta nasional non devisa adalah berjumlah 30 bank. Teknik pengambilan sampel dalam penelitian ini dengan cara non probabilitas dengan menggunakan metode purposive sampling. Dengan kriteria sampel : 
1. Seluruh bank umum swasta nasional yang telah go publik dan terdaftar di Bursa Efek Indonesia.

2. Bank umum swasta nasional yang tidak melakukan merger selama periode 20122016.

3. Bank umum swasta nasional non devisa yang bukan bank syariah. penelitian.

Maka terdapat 9 bank yang menjadi sampel

\section{Jenis dan Sumber Data}

Jenis data yang digunakan dalam penelitian ini adalah data kuantitatif. Menurut Silalahi (2010 : 282), data kuantitatif merupakan data hasil serangkaian observasi atau pengukuran yang dinyatakan dalam angka. Data kuantitatif berdasarkan klasifikasi waktu dapat di kategorikan sebagai data time series (runtut waktu), cross section dan data panel. Dalam penelitian ini data yang digunakan adalah data panmel /pooled data, yaitu gabungan antara data time series dan data cross section.

Sumber data yang digunakan dalam penelitian ini adalah data sekunder. Data yang digunakan dalam penelitian diperoleh dari Indonesian Capital Market Directory (ICMD), Indonesia Stock Exchange (IDX), Otoritas Jasa Keuangan (OJK), dan Badan Pusat Statistik (BPS).

\section{Metode Analisis Data}

Teknik analisis data yang digunakan dalam penelitian ini adalah menggunakan regresi data panel dengan bantuan program Eviews 6 . Regresi data panel merupakan teknik regresi yang menggabungkan data time series dengan cross section.
Model persamaan regresi data panel dalam penelitian ini adalah sebagai berikut:

$$
\begin{aligned}
& Y=\beta_{0}+b_{1} X_{1 i-t}-b_{2} X_{2 i-t}+b_{3} X_{3 i-t}+b_{4} X_{4 i-t}+b \\
& { }_{5} X_{5 i-t}-b_{6} X_{6 i-t}+e_{i-t}
\end{aligned}
$$

Keterangan:

$Y=$ Variabel Dependen

$\mathrm{X}=$ Variabel Independen

$\mathrm{Y}=$ Capital buffer

$\beta_{0}=$ konstanta

$\mathrm{b}_{1}-\mathrm{b}_{7}=$ koefisien regresi

$\mathrm{X}_{1}=$ Non Performing Loan pada unit i pada periode $\mathrm{t}$

$\mathrm{X}_{2}=$ Gross Domestic Product pada unit $\mathrm{i}$ pada periode $t$

$\mathrm{X}_{3}=$ Retrun on Equity pada unit $\mathrm{i}$ pada periode $\mathrm{t}$

$\mathrm{X}_{4}=$ Loan Growth pada unit i pada periode $\mathrm{t}$

$\mathrm{X}_{5}=$ Loan To Total Assets pada unit $\mathrm{i}$ pada periode $t$

$\mathrm{X}_{6}=$ Size pada unit i pada periode $\mathrm{t}$

$\mathrm{e} \quad=$ error term pada unit i pada periode $\mathrm{t}$

\section{HASIL PENELITIAN DAN PEMBAHASAN}

\section{Hasil Analisis Dan Pengujian Hipotesis}

Untuk membuktikan hipotesis penelitian yang dilakukan, maka digunakan analisis regresi data panel. Dalam melakukan analisis, digunakan alat bantu komputer pada program Eviews 9 dengan model estimasi yang dihasilkan yaitu Fixed Effect Model. Setelah data dianalisis, maka diperoleh persamaan fungsi sebagai berikut :

Buffer $=-6.237732+0.075804 \mathrm{NPL}+0.035360$ GDP + $0.035360 \mathrm{ROE}+0.006194$ LOANS - 1.201592 LOTA + 4.336493 Size

\section{Hasil Estimasi dengan Fixed Effect Model}

\begin{tabular}{|l|l|l|l|l|l|}
\hline \multicolumn{4}{|l|}{ Variabel Dependen : Capital buffer } & \\
\hline Variabel & Coeficient & Std. Error & t-statistic & Prob. & \\
\hline C & -6.237732 & 4.316768 & -1.445001 & 0.1532 & \\
\hline NPL? & 0.075804 & 0.032053 & 2.364949 & 0.0210 & \\
\hline GDP & 0.035360 & 0.031626 & 1.118068 & 0.2676 & \\
\hline ROE? & 0.035360 & 0.010557 & 0.177827 & 0.8594 & \\
\hline LOANS? & 0.006194 & 0.002197 & 2.818770 & 0.0064 & \\
\hline LOTA? & -1.201592 & 0.324010 & -3.513320 & 0.0008 & \\
\hline Size? & 4.336493 & 2.353307 & 1.842723 & 0.0699 & \\
\hline & & & & & \\
\hline Intercept & Value & Intercept & Value & Intercept & Value \\
\hline
\end{tabular}




\begin{tabular}{|c|c|c|c|c|c|}
\hline _PBAI_2012_C & 0.974533 & _PBIP_2012_C & -0.138673 & _PBNB_2012_C & 1.545415 \\
\hline _PBAI_2013_C & 0.720602 & _PBIP_2013_C & 0.095331 & _PBNB_2013_C & 0.819152 \\
\hline _PBAI_2014_C & -0.175919 & _PBIP_2014_C & 0.691116 & _PBNB_2014_C & 0.661274 \\
\hline _PBAI_2015_C & 0.257112 & _PBIP_2015_C & 0.289647 & _PBNB_2015_C & 0.240646 \\
\hline _PBAI_2016_C & 0.563982 & _PBIP_2016_C & 0.168980 & _PBNB_2016_C & -0.089238 \\
\hline _PBDI_2012_C & 1.814633 & _PBME_2012_C & -0.675561 & _PBVI_2012_C & -1.145544 \\
\hline _PBDI_2013_C & 1.288886 & _PBME_2013_C & -0.622421 & _PBVI_2012_C & -0.819585 \\
\hline _PBDI_2014_C & 0.504211 & _PBME_2014_C & -0.574344 & _PBVI_2012_C & -0.832722 \\
\hline _PBDI_2015_C & 0.622467 & _PBME_2015_C & -0.472767 & _PBVI_2012_C & -0.868268 \\
\hline _PBDI_2016_C & 0.460510 & _PBME_2016_C & -0.433847 & _PBVI_2012_C & -1.155778 \\
\hline _PBHI_2012_C & -0.549048 & _PBMN_2012_C & 0.072944 & _PBYB_2012_C & -1.086324 \\
\hline _PBHI_2013_C & -0.257102 & _PBMN_2013_C & -0.041088 & _PBYB_2012_C & -0.362916 \\
\hline _PBHI_2014_C & -0.369776 & _PBMN_2014_C & -0.261178 & _PBYB_2012_C & -0.571712 \\
\hline _PBHI_2015_C & -0.068017 & _PBMN_2015_C & -0.733899 & _PBYB_2012_C & -0.737512 \\
\hline _PBHI_2016_C & 0.244946 & _PBMN_2016_C & -0.451260 & _PBYB_2012_C & 0.231067 \\
\hline \multicolumn{6}{|c|}{ R-squared $=0.970370$} \\
\hline \multicolumn{6}{|c|}{ Adjusted R-squared $=0.947923$} \\
\hline \multicolumn{6}{|c|}{ Prob. F statistic $=0.00000$} \\
\hline \multicolumn{6}{|c|}{ DW statistic $=2.635723$} \\
\hline
\end{tabular}

Dari hasil pengujian menggunakan fixed effect model Determinant capital buffer pada bank swasta non devisa di Indonesia diperoleh R2 sebesar 0,970370. Artinya variabel bebas (NPL, GDP, ROE, LOG, LOTA, dan Size) yang ada dalam model dapat menjelaskan Capital buffer sebesar 97,03\% sedangkan $2.97 \%$ sisanya dijelaskan oleh variabel lain di luar model.

Sedangkan hasil uji hipotesis adalah sebagai berikut :

1. Variabel NPL pada masing-masing sampel berpengaruh secara signifikan terhadapat tingkat capital buffer yang dimiliki bank. Hal ini ditunjukkan dengan nilai probabilitas tstatistik untuk variabel NPL sebesar 0.0210. dimana nilai probabilitas tersebut $<0,05$ maka $\mathrm{H}_{0}$ ditolak.

2. Variabel GDP dengan menggunakan nilai logaritma dari data murni memiliki tingkat probabilitas 0,2676 . Nilai tersebut $>$ dari tingkat alpha yaitu 0,05 . Maka $\mathrm{H}_{\mathrm{a}}$ ditolak dan variabel GDP memiliki pengaruh tidak signifikan terhadap capital buffer.

3. Hasil serupa diperolah untuk variabel ROE dengan tingkat probabilitas 0,8594 . Nilai tersebut > dari tingkat alpha yaitu 0,05. Maka $\mathrm{H}_{\mathrm{a}}$ ditolak dan variabel GDP memiliki pengaruh tidak signifikan terhadap capital buffer.

4. Untuk variabel pertumbuhan kredit (Loans) dengan hasil 0,0064 . Nilai tersebut $<$ dari tingkat alpha yaitu 0,05 . Maka $\mathrm{H}_{0}$ ditolak. Sehingga dapat disimpulkan bahwa vaariabel pertuumbuhan kredit memiliki pengaruh tidak signifikan terhadap capital buffer.

5. Hasil serupa pula Untuk variabel rasio kredit terhadap aset (LOTA) dengan hasil 0,0008. Nilai tersebut < dari tingkat alpha yaitu 0,05. Maka $\mathrm{H}_{0}$ ditolak. Sehingga dapat disimpulkan bahwa vaariabel pertumbuhan kredit memiliki pengaruh tidak signifikan terhadap capital buffer. 
6. Sedangkan untuk variabel ukuran perusahaan (Size) memiliki tingkat probabilitas 0,0699. Nilai tersebut $>$ dari tingkat alpha yaitu 0,05 . Maka $\mathrm{H}_{\mathrm{a}}$ ditolak dan variabel GDP memiliki pengaruh tidak signifikan terhadap capital buffer.

\section{Pembahasan}

Model penelitian untuk analisis determinan capital buffer yang digunakan adalah fixed effect model. model ini memberikan tingkat determinasi $\mathrm{R}^{2}$ sebesar $97,03 \%$. Sehingga validitas capital buffer dapat dijelaskan oleh variabel-variabel independen 97,03\%. Melalui model ini juga dihasilkan F-statistik 0.00000 yang menunjukkan bahwa secara bersama-sama variabel independen berpengaruh terhadap variabel dependen. Sedangkan untuk hasil t-statistik akan dijelaskan sebagai berikut.

\subsubsection{Pengaruh Non Performing Loan terhadap capital buffer}

Variabel NPL memberikan hasil estimasi tanda koefisien yang positif sesuai dengan hipotesis awal. Hasil t-test menunjukkan bahwa variabel NPL memiliki pengaruh yang signifikan terhadap capital buffer.

Dengan menyisihkan dana cadangan risiko NPL, bank mampu memelihara fungsinya sebagai lembaga intermediasi sehingga menjamin kepercayaan masyarakat terhadap perbankan. Konsekuensinya, penambahan dana cadangan risiko NPL lebih bersifat kuratif (mengatasi masalah reputasi).Di sisi lain, dengan memupuk dana cadangan kredit, perbankan dapat meningkatkan fungsi intermediasinya dalam rangka mendorong pertumbuhan ekonomi. Dengan demikian, dana cadangan kredit bersifat preventif untuk mengantisipasi prospek ekonomi di masa mendatang.

Hasil penelitian terdahulu yang dilakukan oleh Anna Kundin (2004) dan Jokipi T. \& Milne A (2008) juga menunjukan hasil yang sama. Hasil ini mendukung pendapat Francessco D'Avack (2007) yang mengatakan bahwa bank dengan tingkat kredit macet tinggi akan menggunakan modal (capital buffer) untuk meningkatkan reputasinya. Itulah sebabnya bank dengan NPL tinggi memiliki capital buffer yang cenderung tinggi pula.
4.1.1.2 Pengaruh GDP terhadap capital

Variabel GDP memberikan hasil estimasi tanda koefisien yang positif. Hasil t-test menunjukkan bahwa variabel GDP tidak memiliki pengaruh yang signifikan terhadap capital buffer. Namun, hasil regresi sederhana menunjukan adanya hubungan positif dan signifikan antara GDP dan pertumbuhan kredit bank. Sehingga dapat dikatakan bahwa bank akan tetap menyediakan capital buffer dalam jumlah yang cukup meskipun kondisi ekonomi sedang baik dan penyaluran kredit meningkat.

$\mathrm{Hal}$ ini terbukti dengan dikeluarkannya Peraturan Bank Indonesia No. 17/22/PBI/2015 tentang Kewajiban Pembentukan Countercyclikal Buffer. Dikeluarkannya peraturan tersebut untuk melindungi sistem perbankan dari prilaku menyimpang bank yang melakukan penyaluran kredit besar-besaran ketika kondisi ekonomi membaik. Hasil penelitian ini menunjukan bahwa bank swasta nasional non devisa di Indonesia telah mengimplementasikan pertauran yang ditetapkan. Hasil penelitian ini didukung oleh penelitian yang dilakukan Atici \& Gusoy (2013) dan Jokipi T. \& Milne A (2008).

\subsubsection{Pengaruh Return on equity terhadap capital buffer}

Variabel ROE memberikan hasil estimasi tanda koefisien yang positif sesuai dengan hipotesis awal penelitian. Hasil t-test menunjukkan bahwa variabel ROE tidak memiliki pengaruh signifikan terhadap capital buffer. Return on equity (ROE) adalah jumlah imbal hasil dari laba bersih terhadap ekuitas.

Hasil ini sejalan dengan penelitian D'Avack (2007) dan Fauzia (2016) yang juga menemukan hubungan positif tidak signifikan antara ROE dan capital buffer.Sedangkan penelitian yang dilakukan oleh Atici (2013) mendapatkan hasil tidak signifikan pada bank komersial namun hasilnya menjadi positif signifikan jika menambahkan bank investasi.

\subsubsection{Pengaruh Loan Growth terhadap capital buffer \\ Variabel LOAN (pertumbuhan kredit)} memberikan hasil estimasi tanda koefisien yang positif sesuai dengan hipotesis awal penelitian. Hasil t-test menunjukkan bahwa variabel LOANS memiliki pengaruh yang signifikan terhadap capital buffer. Tanda positif menunjukkan bahwa semakin tinggi jumlah kredit yang disalurkan bank semakin tinggi pula cadangan modal yang disediakan bank. 
Hasil ini juga mengisyaratkan bahwa Indonesia sedang berupaya untuk memperbaiki sistem perbankan. Hal ini ditunjukkan dengan dikeluarkannya Peraturan Bank Indonesia Nomor 15/12/PBI/2013 Tentang Kewajiban Penyediaan Modal Minimun Bank Umum yang mengharuskan semua bank umum menyediakan sejumlah modal tertentu sesuai dengan profil risiko masing-masing bank. Terbukti dengan hasil penelitian yang menunjukkan bahwa semakin tinggi jumlah kredit bank semakin tinggi pula capital buffer yang dimiliki. Hasil ini mendukung hasil penelitian yang dilakukan oleh Atici (2013) pada perbankan Turkey.

\subsubsection{Loan to Total Assets berpengaruh negatif terhadap capital buffer}

Variabel LOTA memberikan hasil estimasi tanda koefisien yang negatif tidak sesuai dengan hipotesis awal penelitian. Hasil t-test menunjukkan bahwa variabel LOTA memiliki pengaruh yang signifikan terhadap capital buffer.

Hubungan negatif antara LOTA dengan capital buffer menunjukkan bahwa bank mengambil risiko yang lebih besar dengan aset yang dimiliki sehingga memutuskan untuk menahan capital buffer yang lebih kecil. Hal itu disebabkan kredit yang disalurkan oleh bank didanai dengan aset yang dimiliki (Fonseca dan Gonzalez, 2013).Hasil ini bertentangan dengan hasil yang diperoleh pada variabel Loans. Hal mengindikasikan bahwa sebagian besar kredit yang disalurkan didanai oleh aset bank dan kredit yang disalurkan adalah bersifat jangka panjang sehingga memiliki tingkat pengembalian yang lama. Hasil ini didukung oleh penelitian yang dilakukan Bayuseno (2014) dan Fauzia (2016)

\subsubsection{Size memiliki pengaruh positif terhadap capital buffer}

Variabel Size memberikan hasil estimasi tanda koefisien yang positif tidak sesuai dengan hipotesis awal penelitian. Hasil t-test menunjukkan bahwa variabel Size memiliki pengaruh yang tidak signifikan terhadap capital buffer. Sehingga dapat disimpulkan bahwa ukuran bank tidak mempengaruhi jumlah capital buffer bank. Hal ini disebabkan karna semua bank yang menjadi sampel penelitian memiliki jumlah asset yang relatif hampir sama sehingga tidak ada data yang merupakan pembanding. Besarnya jumlah aset yang relatif sama ini bisa jadi disebabkan karna semua bank sampel berada pada kelompok yang sama berdasarkan ukurannya.
Hasil ini tidak sesuai dengan Too Big To Fail Consensus yang berpendapat bahwa semakin besar bank semakin kecil jumlah cadangan modal yang dimiliki. Sekali lagi hal ini membuktikan bahwa sistem perbankan Indonesia benar-benar telah dilaksanakan dengan baik sehingga memperkecil kemungkinkan kemungkinan bank untuk melakukan prilaku yang berisiko (moral hazard). Hasil ini didukung oleh penelitian yang dilakukan oleh Haryanto (2015) dan Legri (2017).

\section{KESIMPULAN DAN SARAN}

\section{Kesimpulan}

Berdasarkan hasil penelitian dapat ditarik beberapa kesimpulan sebagai berikut.

1. Tingginya NPL akan meningkatkan jumlah cadangan modal (capital buffer) hal ini dilakukan dengan dua tujuan yaitu untuk meningkatkan reputasi dan menghindarkan dari risiko permodalan.

2. Peningkatan GDP akan meningkatkan jumlah capital buffer meskipun dalam tingkat yang kecil. Hal ini dikarenakan adanya peningkatan jumlah penyaluran kredit pada kondisi ekonomi yang baik sehingga bank perlu menambah cadangan modal sebagai penyangga dari risiko kredit.

3. Peningkatan ROE pada bank akan menyebabkan peningkatan jumlah capital buffer disebabkan karna pada perusahaan perbankan, penggunaan dana internal dianggap lebih mahal sehingga bank lebih memilih menggunakan dana ekternal.

4. Semakin tinggi jumlah kredit yang disalurkan bank (LOAN) semakin tinggi pula cadangan modal yang disediakan bank. Hal ini membuktikan bahwa perbankan di Indonesia memiliki tingkat risiko yang tidak membahayakan dan dapat melindungi dana nasabahnya.

5. Peningkatan loan to total assets dapa menyebabkan penurunan jumlah capital buffer bank karna kredit yang disalurkan bank didanai oleh aset dan bersifat jangka panjang. Sehingga memiliki periode pengembalian yang lama.

6. Ukuran bank juga mempengaruhi capital buffer bank meskipun dalam tingkat yang rendah. Semakin besar suatu bank akan menyebabkan semakin tinggi capital buffer yang disediakan. 


\section{Saran}

Berdasarkan hasil penelitian, maka penulis memberikan beberapa saran,

yaitu sebagai berikut:

1. Bagi manajemen perbankan, disarankan untuk melakukan analisis terhadap risiko kredit yang mungkin menimpa karna penyaluran kredit yang bersifat jangka panjang terlebih jika kredit tersebut dibiayai oleh aset jangka pendek.

2. Peneliti selanjutnya diharapkan dapat menambah periode tahun pengamatan yang digunakan agar sampel yang diteliti lebih banyak, hasil yang lebih akurat dan bisa lebih mencerminkan kondisi sesungguhnya dilapangan.

3. Peneliti selanjutnya dapat menambah jumlah sampel penelitian dengan memasukkan bank-bank investasi.

4. Peneliti selanjutnya disarankan untuk menggunakan bank dengan ukuran yang berbeda dari aspek asset.

5. Banyak indikator yang dapat digunakan untuk menggambarkan variabel independen dan dependen dalam penelitian ini. Oleh karena itu, untuk penelitian selanjutnya diperlukan uji awal untuk menentukan indikator yang paling kuat dalam menjelaskan variabel-variabel, lalu kemudian digunakan dalam penelitian selanjutnya.

\section{DAFTAR PUSTAKA}

Bouvatier, V., dan Lepetit, L. (2012). Effect of Loan Loss Provisions on Growth in Bank

Atici, Gonca \& Guner Gursoy. (2013).Determinan of Capital buffer in the Turskish Banking System. International Business Research, Vol. 6, No.

Bayuseno, Vidrata. (2015). Analisis Faktor yang Mempengaruhi Capital buffer Perbankan di Indonesia Studi pada Bank Konvensional Go Publik. Universitas Diponegoro

Agnes, Sawir. 2005. Analisis Kinerja Keuangan dan Perencanaan Keuangan Perusahaan. Jakarta: Gramedia Pustaka Utama.

Aniruddha Durafe. (2013). Bank's Capital buffer and Business Cycle : Evidence For India. Anvesha Vol. 8 (2)

Decisions when Firm Have Information that Investors Do Not Have". Journal of Financial Economics, Vol. 13

Dr. Ulber Silalahi, MA. (2010). Metode Penelitian Sosial. Refika Aditama. Bandung.
Erkens, David H. Mingyi Hung, \& Pedro Matos. (2012). Coorporate Governance in the 20072008 Financial Crisis : Evidence from Financian Institutions Worldwile. Journal of Coorporate Finance 18.

Fauzia, Nanda Arum. Idris. (2016). Analisis FaktorFaktor Yang Mempengaruhi Capital Buffer (Studi Kasus Pada Bank Umum Konvensional yang Terdaftar di BEI Tahun 2011-2014)

Fikri, Ramizul Moh., 2012. The Determinants of Capital buffers Commercial Banks in Indonesia (Study on 16 Biggest Commercial Banks Period 2004-2010. Thesis for Bachelor Program of Economic Faculty Diponegoro University.

Francesco D'Avack \& Sandrine Levassuer. (2007). The Determinant of Capital buffer in CEECs.

Jokipii, T., Milne, A. (2008), The cyclical behavior of European bank capital buffers. Journal of Banking and Finance, 32.

Haryanto, Sugeng.(2015). Determinan Capital buffer : Studi Empirik Industri Perbankan Nasional.

Kane, E. J., _007(a). Basel II: A Contracting Perspective. Journal of Financial Services Research, 32(1-2)

Lending: Some International Comparisons. International Economics, Vol. 132

Myers, Stewart C dan Nicholas S. Majluf, 1984. "Corporate Financing and Investment

Mishkin, Frederic S.(2006). How Big a Problem is Too Big to Fail? A Review of Gary Stern and Ron Feldman's Too Big to Fail : The Hazard of Bank Bailouts. Journal of Economic Literature. Vol. XLIV.

Rochet, J.C. (1992), Capital requirements and the behaviour of commercial banks. European Economic Review, 36

Rose, Peter. S, 2002. Commercial Bank Management, McGraw-Hill, Boston.

Syaifuddin, Dedy Takdir (2009). Efisiensi dan Kinerja Bank. Unhalu Ekspres. Kendari 